\title{
Working During Pandemic: The Factors of Workstation Ergonomics and Complaints for Concerning the Body
}

\author{
Mas'udah Asmui, Noor Dalila Musa, Mohd Zaidi Mat Saat, Mastura \\ Mohamad, Sharifah Norhuda Syed Wahid
}

To Link this Article: http://dx.doi.org/10.6007/IJARBSS/v11-i10/11025

DOI:10.6007/IJARBSS/v11-i10/11025

Received: 12 August 2021, Revised: 16 September 2021, Accepted: 30 September 2021

Published Online: 07 October 2021

In-Text Citation: (Asmui et al., 2021)

To Cite this Article: Asmui, M., Musa, N. D., Saat, M. Z. M., Mohamad, M., \& Wahid, S. N. S. (2021). Working During Pandemic: The Factors of Workstation Ergonomics and Complaints for Concerning the Body. International Journal of Academic Research in Business and Social Sciences, 11(10), 572 - 582.

Copyright: (c) 2021 The Author(s)

Published by Human Resource Management Academic Research Society (www.hrmars.com) This article is published under the Creative Commons Attribution (CC BY 4.0) license. Anyone may reproduce, distribute, translate and create derivative works of this article (for both commercial and non-commercial purposes), subject to full attribution to the original publication and authors. The full terms of this license may be seen at: http://creativecommons.org/licences/by/4.0/legalcode

Vol. 11, No. 10, 2021, Pg. 572 - 582

Full Terms \& Conditions of access and use can be found at http://hrmars.com/index.php/pages/detail/publication-ethics 


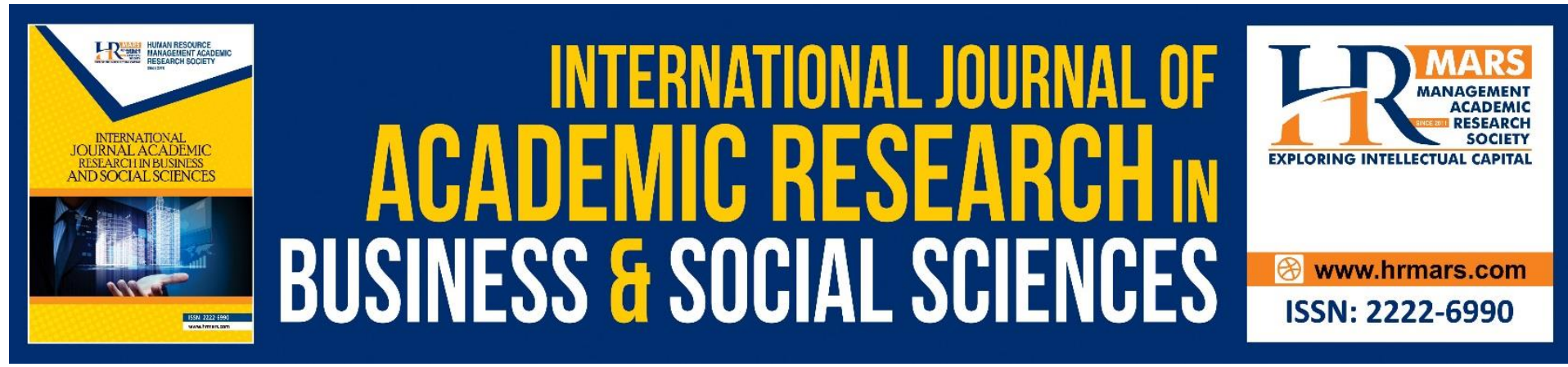

\title{
Working During Pandemic: The Factors of Workstation Ergonomics and Complaints for Concerning the Body
}

\author{
Mas'udah Asmui ${ }^{1}$, Noor Dalila Musa ${ }^{1}$, Mohd Zaidi Mat Saat ${ }^{1}$, \\ Mastura Mohamad ${ }^{1}$, Sharifah Norhuda Syed Wahid ${ }^{2}$ \\ ${ }^{1}$ Faculty of Business and Management, Universiti Teknologi MARA, Pahang Branch \\ ${ }^{2}$ Faculty of Computer and Mathematical Sciences, Universiti Teknologi MARA, Pahang \\ Branch \\ Email:mas_as@uitm.edu.my,noordalila@uitm.edu.my,mohdzaidi@uitm.edu.my, \\ masturamohdd@uitm.edu.my, sha_norhuda@uitm.edu.my
}

\begin{abstract}
Working from home during pandemic has become a new practice after Covid-19 pandemic spreads globally. Education sectors are closed temporarily where academicians are required to conduct online learning session. Working at home has been challenging with less or no ergonomic elements especially on the teaching and learning facilities. The impact of less or zero ergonomics elements at workstation may contribute to short and long-term effects to physical and mental health. Spending long hours at work areas in front of the computer for getting the video and notes ready, composing records and meeting students on computer, sitting on regular seat that existed at home, feeling tense due to computer and technology illiteracy, as well as enduring body torments and stress are among the impacts of working at home during this pandemic. Nonetheless, this new normal needs to be adjusted and adapted immediately. This research aims to investigate the four factors of workstation ergonomic aspects; body position, health level, teaching and learning tools and chair seating that contribute to their body conditions level at early Covid-19 pandemic. Besides, this research focuses to examine the relationship between the four factors and complaints concerning body conditions among academicians in Universiti Teknologi MARA, Pahang Branch when working at home. It was discovered that body posture was the most important aspect of workstation ergonomics despite having a minor impact on academicians' overall body health. Next, academicians' health level played a minor role in workstation ergonomics although it has a significant impact on academicians' complaints about their bodies.
\end{abstract}

Keywords: Ergonomics, Academicians, Body Posture, Health Level, Teaching and Learning Tools, Chair Seating, Complaints Concerning the Body

\section{Introduction}

Before 2020, it took nearly 40 years for homeworkers' population to increase by three percent, but its occurrence increased eight-fold almost overnight as people were instructed to work from home when possible due to the pandemic (Felstead and Reuschke, 2021). As 
the COVID-19 pandemic spread in early 2020, workers shifted into their home office, which may not fit them ergonomically (Davis et al., 2020). Davis et. al (2020) further claimed that employees engage in more screen time rather than before, and they spend long durations in office areas (at home) that are poorly designed for long-term use (Davis et. al., 2020). Social interaction can be difficult to accomplish remotely, but the right workspace can ease some of the challenges and ensure you are at your best (Patrick, 2020).

Working at home has increased and improved productivity as workers need to commute less to office building and use more time doing work at home with flexible time. Spending long hours at work desks to use computer for preparing video notes, typing documents and meeting students on computer, sitting on regular chair which existed at home, feeling tense due to incompetent with computer technology and suffering body pains and stress are among the effects of working at home during pandemic Covid-19. Sadly, this new normal has to be adapted and absorbed instantly for many workers including academicians.

The announcement made by the Ministry of Higher Education which declared that both public and private universities in Malaysia will be involved in online teaching and learning activities until the end of December 2020 (Malaysian Ministry of Higher Education, 2020), has automatically enforced the university academicians to stay at home and continuously carry out the online distant learning. Therefore, most of the academicians have to set up home offices appropriately so that they do not experience discomfort or induce health problems. Among the issues confronted by the workers are on preparing and arranging workstation at home, in addition to the difficulties to reach comfortability and 'to resemble working in actual office environment'. Furthermore, they need to ensure that their health is kept as a result of having to deal with new and diverse work settings. The objective of this research is to investigate the four factors of workstation ergonomic aspects which are body position, health level, teaching and learning tools and chair seating, that contribute to their body condition level during early Covid-19 pandemic. Moreover, the objective is also to examine the relationship between the four factors and complaints concerning the body conditions among academicians in Universiti Teknologi MARA, Pahang Branch when working at home.

\section{Literature Review}

Since the COVID-19 outbreak, working from home (WFH) has become the new normal for many workers with office-based jobs (Sostero, Milasi, Hurley, Fernández-Macías, \& Bisello, 2020; Hallman, Januario, Marthiassen, Heiden, Svensson and Bergstrom, 2021). The sudden mass shift by the coronavirus crisis created what has been called the largest work-from-home experiment in history (Patrick, 2020). Employees were expecting flexibility to manage their own working hours through flexible working arrangements like adaptable working hours, rotating working hours, hybrid working models and working at home.

Besides, to set new office at home, many people have constraints with their budgets, limited access to suitable chairs, desks, input devices and the environment that does not support a home office (Davis et. al., 2020). As a result, four workstation ergonomics factors will be investigated in this study: body position, health level, teaching and learning tools, and chair seating. 


\section{Body Position}

According to Viera and Kumar (2004), body position becomes one of the important factors of work ergonomics to ensure an employee can perform their job without exposing them to health issues. Majority of employees have a laptop or desktop to work at home, however, this sometimes resulted in poor postures of the back and neck due to placing the laptop on the lap or setting it on the desk. It may happen due to the monitor of the laptop or desktop being too low which requires the employees to look down frequently for a long period of time (Davis et al., 2020).

\section{Health Level}

During the COVID-19 pandemic, the increment of WFH may have both beneficial and negative effects on working conditions, as well as physical and mental health among employees (Hallman et al. 2021; Bouziri, Smith, Descatha, Dab, \& Jean, 2020). WFH virtually comes with a variety of beneficial results (Heath, Hoey \& Aslett, 2020). For example, a previous study has mentioned that WFH results in spending less time on commuting between home and work, as well as reduced fatigue, traffic congestion, and other environmental issues, are some of the advantages of WFH, as well as enhanced flexibility, productivity, and work-life balance (Allen, Golden, Shockley, 2015). In addition, Morreti, Menna, Aulicino, Paoletta, Liguori and lolascon (2020) proved that WFH gives financial benefits to workers, such as lower transportation costs and lower spending on snacks or food items while at work. However, the blurring of physical and organisational boundaries between work and home can also negatively impact an individual's mental and physical health due to extended hours, lack of or unclear delineation between work and home, and limited support from organisations (Allen et al., 2015; Oakman et al., 2020). Those with more working days at home experienced greater emotional exhaustion and cognitive stress associated with reduced social support from their colleagues (Oakman et al., 2020).

\section{Teaching and Learning Tools}

Workers were shifted from the office to their homes with their laptops in hand, faced with the need to set up an office area with what they had at home: dining tables and chairs and other makeshift desks, no external input devices or monitors, and environments with dual functions that could be used by multiple people (e.g., kids for school, adults for work, and family for dinner) (Davis et al., 2020). However, this new norm of WFH can create negative impacts on employees' performance if the employees don't expose themselves with proper working conditions which are also known as ergonomics. Ergonomics is the best way to confirm an employees' task, tools and equipment, and physical atmosphere closely match with employees' needs and wants (Quible, 2019).

\section{Chair Seating}

Chairs or seats for home office are among the ergonomic factors that should be taken into consideration. A study from Wojcikiewicz (2003) determined the three functions of chairs used by an employee to increase employees' effectiveness, minimize fatigue and stress while performing their tasks, and fit the body posture. Cook, Burgess and Papalia (2004) believed that strains at neck, shoulder, and arm muscles can be reduced if the employees use chairs with armrests and have adjustable function. It was suggested by Davis et al. (2020) that there are four key components of the best chairs to be used by an employee: adjustable height, adjustable armrests, five casters, and lumbar support in the back of the chair. Ergonomic 
chair is important since it is a contributing factor that helps the employees to complete their task faster and at the same time can minimize the level of work stresses (Beckett, 1995).

\section{Complaints Concerning the Body}

These home offices may not be ergonomically designed for the worker, resulting in a rapid onset of body discomfort that could lead to more significant problems in the future (Davis et al., 2020) such as eye strain, carpal tunnel syndrome, and back pain and limbs. Furthermore, unlike office work environments where extensively availability of comfy office furniture, wellequipped electronic machines, and air conditioning systems, workers may not focus to organize indoor environmental quality ambiance at home. That, in turn, has an impact on people's mental and physical health due to organisational, physical, environmental, and psychological aspects.

\section{Methodology}

Primary data was collected in this study using a set of questionnaire which was distributed online via a Google Form format, and a total of 73 lecturers from Universiti Teknologi MARA Pahang answered the survey voluntarily. The questionnaire used in the study was divided into three parts; Part 1 comprised questions on respondents' demographic background, Part 2 comprised questions on factors of workstation ergonomics and Part 3 consisted of questions on physiological (body health level complaints). The questions for Part 2 was adapted from four previous studies (Brief \& Aldag, 1976; Tate et al., 1997; Hedge \& Erickson, 1997; Makhbul \& Hasun, 2007) while the questions for Part 3 was adapted from three previous studies (Karasek, 1979; Ekman \& Ehrenberg, 2002; Makhbul \& Hasun, 2007). All the questions for Part 2 and 3 are in a 5-point Likert-scale format that ranges from 1 (strongly disagree) to 5 (strongly agree). The data analyses included descriptive, correlation and multiple linear regression analyses using IBM-SPSS version 24 software. Furthermore, normality test shows that all the variables of interest are approximately normally distributed so that the correlation and multiple linear regression analyses can be conducted.

In this study, respondent's complaints for concerning the body as the response variable, $(\mathrm{Y})$ to be predicted by the four factors. The regression model obtained can be written as

$$
Y=\beta_{0}+\beta_{1} X_{1}+\beta_{2} X_{2}+\beta_{3} X_{3}+\beta_{4} X_{4}+\varepsilon_{1}
$$

where $X_{1}=$ body posture, $X_{2}=$ health level, $X_{3}=$ teaching and learning tools, $X_{4}=$ chair seating and $\varepsilon_{i}$ is the model error which assumed to be normally distributed with constant variance.

\section{Results}

In total 54 (74.0\%) female respondents were involved in this study and the rest are males (19, $26.0 \%)$, whereby 37 (50.7\%) of them are from science and technology field and 36 (49.3\%) are from social science field. In addition, their educational backgrounds are mostly Master's Degree $(53,72.6 \%)$ and Doctor of Philosophy graduates $(20,27.4 \%)$.

As shown in Table 1 below, body posture was identified as the highest contributed factor on workstation ergonomics during working in pandemic among respondents $(M=4.02, S D=.67)$ followed by teaching and learning tools used $(M=3.88, S D=.63)$, health level $(M=2.71, S D$ 
$=.94)$ and chair seating $(M=2.59, S D=.83)$. Meanwhile, the response variable, complaints concerning the body was in neutral score $(M=2.64, S D=.84)$.

Table 1. Descriptive Analysis

\begin{tabular}{lll}
\hline Variables of Interest & Mean, $M$ & Standard Deviation, SD \\
\hline Factors on workstation ergonomics & & \\
Body posture & 4.02 & .67 \\
Health level & 2.71 & .94 \\
Teaching and learning tools & 3.88 & .63 \\
Chair seating & 2.59 & .83 \\
Response & & \\
Complaints for concerning the body & 2.64 & .84 \\
\hline
\end{tabular}

The following Table 2 displays the correlations between the factors of workstation ergonomics and complaints concerning the bodies' level. Result indicates that there exists significant positive relationship between health level and complaints for concerning the body $(r=.718, p<.001)$. In addition, result also reveals that there exists significant positive relationship between body posture and complaints for concerning the body $(r=.400, p<$ $.001)$. Meanwhile, teaching and learning tools and chair seating has negligible correlations with complaints concerning the body $(r=.085, p=.473)$ and $(r=-.196, p=.097)$. Overall, there exists a significant positive relationship between the factors on workstation ergonomics and respondents' complaints regarding their bodies' level $(r=.490, p<.001)$.

Table 2. Correlational Analysis

\begin{tabular}{lll}
\hline Pair & Correlation value & p-value \\
\hline Body posture $\sim$ Complaints for concerning the body & .400 & .000 \\
Health level $\sim$ Complaints for concerning the body & .718 & .000 \\
Teaching and learning tools $\sim$ Complaints for & -.196 & .097 \\
concerning the body & & .473 \\
Chair seating $\sim$ Complaints for concerning the body & .085 & .085
\end{tabular}

A regression analysis was carried out to investigate whether body posture, health level, teaching and learning tools and chair seating could significantly predict respondents' complaints concerning their bodies. As shown in Table 3, regression analysis result shows that the model is significant $\left(\mathrm{F}_{4,68}=23.910, \mathrm{p}\right.$-value $\left.<.001\right)$ with at least one of the factors on workstation ergonomics is significantly affected the respondents' complaints concerning their bodies. In addition, the coefficient of determination value of the model is 0.584 which indicates that the four factors on workstation ergonomics can explain $58.4 \%$ of the variation of respondents' complaints for concerning their body, while the other $41.6 \%$ was explained by other factors. 
Table 3. Analysis of Variance

\begin{tabular}{llllll}
\hline Model & Sum of Squares & $\mathrm{df}$ & Mean Squares & $\mathrm{F}$ & $\mathrm{p}$-value \\
\hline Regression & 29.846 & 4 & 7.461 & 23.910 & .000 \\
Residual & 21.220 & 68 & .312 & & \\
Total & 51.066 & 72 & & &
\end{tabular}

The results of regression analysis also show that the body posture ( $p$-value $<0.01)$ and health level ( $p$-value $<0.001$ ) become significant factors of complaints for concerning the body as stated in Table 4. Among these two significant factors, the health level becomes the most significant and important factor of complaints for concerning the body followed by body posture.

Table 4. Regression Analysis

\begin{tabular}{lllll}
\hline Model & Coefficient & Standardized Beta & $\mathrm{t}$ & $\mathrm{p}$-value \\
\hline Constant & .750 & & 1.317 & .192 \\
Body posture & .296 & .236 & 2.880 & .005 \\
Health level & .576 & .643 & 7.784 & .000 \\
Teaching and learning & -.208 & -.156 & -1.945 & .056 \\
tools & -.019 & -.019 & -.237 & .814 \\
Chair seating & & & \\
\hline
\end{tabular}

The estimated regression model can be written as

$Y=0.750+0.296 X_{1}+0.576 X_{2}$

\section{Discussions}

Chair seating is the least convenience and lack of ergonomic factor at the academicians' workstation. At home, the condition of most chairs does not meet the ergonomic elements. Hence, the academicians often experience pain in the neck and back of the body in conjunction to the need to do work for a long period of time. However, knowledge of the correct body position while typing, using computer, and sitting can assist a person to integrate the ergonomic elements and comfortability within the period of working even on ordinary chair. Working for longer time requires a chair that is able to support weight and can be seated at ease. Despite the lavish cost of an ergonomic chair, it is designed to support the spine and almost the entire limb. It supports the body position and provides better comfort than a dining chair or a regular chair that is available at home.

A career as academician requires one to have a complete set of computers or laptops. Therefore, teaching and learning tools is less issue as compared to health level and chair seating. Unlike the conventional office where the workspaces are usually arranged by employers, during WFH, workers have full autonomy and the responsibility of setting up their workspaces at home, being able to work in a location at home that may have better IEQ conditions as opposed to being in a fixed cubicle or open-plan offices (Kim and de Dear, 2013; Xiao et al., 2021). 
Furthermore, the health level among the academicians had been affected physically and mentally during working in Covid-19 pandemic. Many of them claimed that working at home always makes them feel tense as they spend longer hours at their desks at home. Working in a location that is not designed for work can lead to unsatisfactory IEQ (Indoor environmental quality) conditions that can have detrimental effects on both physical and mental well-being, while also decreasing overall work performance (Mahbob et al., 2011; Xiao et al., 2021).

This research also reported that the academicians did not have a satisfactory level of health and often stayed up at night due to work-related problems. Moreover, during the pandemic, workers can spend longer hours at their desks in the absence of commuting, limited business travelling, and increased use of computers to conduct meetings rather than holding face-toface meetings at various different physical locations (DeFilippis et al., 2020; Kaur and Sharma, 2020; Xiao et al., 2021) in which contribute to body stress and mental tense intensively. Besides, the academicians often wake up from sleep because they feel pain or cramps in muscles or joints that lead to low body health level. Pressure to body due to workspace sharing, poor body mechanics due to lack of proper physical workstation, and prolonged sedentary activity can lead to increased discomfort and pain.

\section{Conclusions}

Despite limitations with a relatively low number of studies, some consistent principles emerge which can be used to support employers in improving working conditions to mitigate the negative effects of WAH, and enhance the positive effects of WAH on employees' health (Oakman et al., 2020). Body posture was the most important aspect of workstation ergonomics, although it had little impact on academicians' overall health. Most academicians felt that a regular practise of sitting properly in a chair (which most of them do for more than two hours) would guarantee good physical health. Sitting properly with accurate seating posture and typing would have a great impact on the health of the backbone and hand.

Regardless of the health level has low issue to the workstation ergonomics, it is found exceptionally to affect the academicians' wellbeing level. This finding lines up with Wickens et al (2004); Makhbul (2012) which expressed that the workers' health level is firmly identified with the stress outcomes at the work environment. The academicians complained that their health level decreased when working from home during the pandemic. They easily get tensed, their level of health fall to dissatisfactory level and could not have a tide sleep at night besides feel pain or cramps in muscles or joints.

The choice to work from home should be made with the employee's health in mind, and considerable knowledge of body position should be imparted to them while they are at work. Academician should consider on spending a significant amount of time in front of a computer. According to Oakman et al (2020) decisions on how to promote employees' health whilst working at home (WAH) need to be based on the best available evidence to optimise worker outcomes. The outcomes of this research are believed to be useful to employers and academicians in future.

Findings from this study have extended beyond the findings of previous studies, therefore have contributed to current information about the ergonomic effects toward body health research. Firstly, the findings are the addition to the empirical study on the correlation among 
the factors of workstation ergonomics and complaints concerning the body among Malaysian academicians. Secondly, there are scarcities of empirical studies among Malaysian academicians, hence there is a need to pursue wider knowledge in this area. It is important to conduct more research within this field to ensure the optimization in the quality of higher educational institutions. Therefore, this study has successfully contributed to extended literature by empirically testing the factors of workstation ergonomics in the Malaysian context. Due to the prolong of Movement Control Order (MCO), there is a need for most of the organizations to continuously implement working from home. Consequently, academicians can take into consideration and employ the outcomes generated from this research to design their home office ergonomically, so that it leads to a positive body health level during COVID-19 pandemic situation.

\section{References}

Allen, T. D., Golden, T. D., \& Shockley, K. M. (2015). How Effective is Telecommuting? Assessing the Status of Our Scientific Findings. Psychological Science in the Public Interest, 16(2), 40-68. https://doi.org/10.1177/1529100615593273.

Beckett, R. (1995). Are You Sitting Comfortably? Facilities, 13(12), 26-27.

Bouziri, H., Smith, D. R. M., Descatha, A., Dab, W., \& Jean, K. (2020). Working from Home in the Time of COVID-19: How to Best Preserve Occupational Health? Occupational \& Environmental Medicine, 77(7), 509-510. https://doi.org/10.1136/oemed-2020-1 06599.

Brief, A. P., \& Aldag, R. J. (1976). Correlates of Role Indices. Journal Applied Psychologoy, 61, 468-472.

Cook, C., Burgess, L. R., \& Papalia, S. (2004). The Effect of Wrist Rests and Forearm Support During Keyboard and Mouse Use. International Journal of Industrial Ergonomics, 33, 463-472.

Davis, K. G., Kotowski, S. E., Daniel, D., Gerding, T., Naylor, J., \& Syck, M. (2020). The Home Office: Ergonomic Lessons from the "New Normal". Ergonomics in Design: The Quarterly of Human Factors Applications, 28(4), 1-7. Retrieved from https://journals.sagepub.com/doi/full/10.1177/1064804620937907.

Defilippis, E., Impink, S. M., Singell, M., Polzer, J. T., Sadun, R. (2020). Collaborating during Coronavirus: The Impact of COVID-19 on the Nature of Work. National Bureau of Economic Research, 1-31. Retrieved from htttp://www.nber.org/papers/w27612.

Ekman, I., \& Ehrenberg, A. (2002). Fatigue in Chronic Heart Failure: Does Gender Make A Difference? European Journal Cardiovascular Nursing, 1(1), 77-82. DOI: 10.1016/S1474-5151(01)00016-0. PMID: 14622871.

Felstead, A., \& Reuschke, D. (2021). "A Flash in The Pan or A Permanent Change? The Growth of Homeworking During The Pandemic and Its Effect on Employee Productivity in The UK", Information Technology \& People, Vol. ahead-of-print No. ahead-ofprint. https://doi.org/10.1108/ITP-11-2020-0758.

Hallman, D. M., Januario, L. B., Mathiassen, S. E., Heidin, M., Svensson, S., \& Bergstrom, G. (2021). Working from home during the COVID-19 outbreak is Sweden: effects on 24-h time-use in office workers. BMC Public Health, 21(528), 1-10. https://doi.org/10.1186/s12889-021-10582-6.

Heath, R., Hoey, C., \& Aslett, J. (2020). Connecting Through COVID. Incite, 41(11/12), 29. http://read.alia.org.au/incite-novemberdecember-2020. 
Hedge, A., \& Erickson, W. A. (1997). A Study of Indoor Environment and Sick Building Syndrome Complaints in Air-Conditioned Offices: Benchmarks for Facility Performance. International Journal of Facility Management, 1(4), 185-192.

Karasek, R. A. (1979). Job Demands, Job Decision Latitude and Mental Strain: Implications for Job Redesign. Administrative Science Quality, 24: 285-307.

Kaur, T., \& Sharma, P. (2020). A Study on Working Women and Work from Home Amid Coronavirus Pandemic. Journal of Xi'an University Architecture \& Technology, XII(V), 400-1408.

Kim, J., \& Dear, R. D. (2013). Workspace Satisfaction: The Privacy-Communication TradeOff in Open-Plan Offices. Journal of Environmental Psychology, 36, 18-26.

Mahbob, N. S., Kamaruzzaman, S. N., Salleh, N., Sulaiman, R. (2011). A Correlation Studies of Indoor Environmental Quality (IEQ) Towards Productive Workplace. 2nd International Conference on Environmental Science and Technology, Vol. 6, 434-438.

Makhbul, Z. M., \& Hasun, F. M. (2007). Ergonomik dan Stres di Malaysia: Implikasi Terhadap Teori, Metodologi dan Pengurusan. Jurnal Pengurusan, V. 26, 99-130.

Makhbul, Z. M. (2012). Correlation Analysis Between Ergonomics and Stress at the Workplace, International Business Management, 6 (6): 648-651. DOI: 10.3923/ibm.2012.648.651.

Malaysian Ministry of Higher Education. (2020). Higher Education Ministry: All University Lectures To Be Online-Only Until End 2020, with a Few Exceptions [Press release]. https://www.malaymail.com/news/malaysia/2020/05/27/higher-education-ministryall-university-lectures-to-be-online-only-until-e/1869975.

Moretti, A., Menna, F., Aulicino, M., Paoletta, M., Liguori, S., \& Iolascon, G. (2020). Characterization of Home Working Population During COVID-19 Emergency: A CrossSectional Analysis. International Journal of Environmental Research and Public Health, 17(17), 6284, 1-12. https://doi.org/10.3390/ijerph17176284.

Oakman, J., Kinsman, N., Stuckey, R., Graham, M., \& Weale, V. (2020). A Rapid Review of Mental and Physical Health Effects of Working at Home: How Do We Optimise Health?. BMC Public Health, 20:1825. https://doi.org/10.1186/s12889-020-09875-z.

Patrick, B. (2020). Ergonomics for the Home Office. Journal of Accountancy. Retrieved from https://www.questia.com/library/journal/1G1630170756/ergonomicsfor-the-home-office.

Quible, Z. K. (2014). Administrative Office Management. 8th ed. Pearson Education Limited.

Sostero, M., Milasi, S., Hurley, J., Fernández-Macías, E., \& Bisello, M. (2020). Teleworkability and the COVID-19 Crisis: A New Digital Divide? European Commission, Joint Research Centre, Seville.

Tate, U., Whatley, A., \& Clugston, M. (1997). Sources and Outcomes of Job Tension: A Threenation Study. International Journal Management, 3:350-358.

Viera, E. R., \& Kumar, S. (2004). Working Postures: A Literature Review. Journal of Occupational of Rehabilitation, 14, 143-159.

Wickens, C. D., Lee, J. D., Liu, Y., \& Gordon-Becker, S. E. (2004). An Introduction to Human Factors Engineering. $2^{\text {nd }}$ ed. Pearson Education, Upper Saddle-River.

Wojcikiewicz, K. (2003). Seven Key factors for Ergonomics Workstation Design. Manufacturing Engineering, 131(1), 45.

Xiao, Y., Becerik-Gerber, B., Lucas, G., \& Roll, S. C. (2020). Impacts of Working from Home During COVID-19 Pandemic on Physical and Mental Well-Being of Office Workstation 
INTERNATIONAL JOURNAL OF ACADEMIC RESEARCH IN BUSINESS AND SOCIAL SCIENCES Vol. 11, No. 10, 2021, E-ISSN: 2222-6990 @ 2021 HRMARS

Users. Journal of Occupational Environment Medical, 63(3): 181-190, 2021. DOI: 10.1097/JOM.0000000000002097. 